\title{
ULTRASOUND AND WATER IMMERSION TO PROMOTING VIGOR IN SEEDS AND SEEDLINGS OF Cnidoscolus quercifolius
}

\section{ULTRASSOM E IMERSÃO EM ÁGUA COMO PROMOTORES DE VIGOR EM SEMENTES E PLÂNTULAS DE Cnidoscolus quercifolius}

\author{
Thiago Costa Ferreira ${ }^{1}$, Manoel Rivelino Gomes de Oliveira², Aldrin Martin Perez-Marin ${ }^{3}$ \\ ${ }^{1,3}$ Instituto Nacional do Semiárido, Campina Grande, Paraíba, Brasil - thiago.ferreira@insa.gov.br \& \\ aldrin.perez@insa.gov.br
}

${ }^{2}$ Universidade Federal da Bahia, Camaçari, Bahia, Brasil - manoel.oliveira@insa.gov.br

\begin{abstract}
Cnidoscolus quercifolius is a common plant species with multiple uses from Brazilian semiarid area (BSA). Their seeds have dormancy. Fact that needs to be resolved in favor of the growing demand to produce seedlings of this species, mainly for the recovery of degraded areas in BSA. Non-acidic technologies such as water immersion and ultrasound are testing to promote uniform emergence and vigor for seeds and seedlings for many species. The objective of this paper was to test ultrasound and immersion in water as technique to promoter vigor and emergence in seeds and seedlings of $C$. quercifolius. Seeds of $C$. quercifolius were submitted to treatments using a $2 \times 4$ factorial scheme [F1 Immersion in water for $24 \mathrm{~h}$ (without and with immersion) and F2 - time of exposure to ultrasound (0, 90, 180 and 270 s)], after they were sown in a bed and analyzed for 21 days with emergence and vigor measurements. Immersion in water for 24 hours is an efficient treatment to improve the vigor and emergence of $C$. quercifolius seeds and seedlings.
\end{abstract}

KEYWORDS: Caatinga biome, Seed Tecnology, Inovation.

\section{RESUMO}

Cnidoscolus quercifolius é uma espécie vegetal comum e de múltiplo uso na área do semiárido brasileiro (SAB) suas sementes apresentam dormência. Fato este que precisa ser resolvido em prol da crescente demanda de produção de mudas desta espécie, principalmente para a recuperação de áreas degradadas no SAB. Tecnologias não-ácidas como a imersão em água e o ultrassom têm sido testadas para promover a uniformidade da germinação para muitas espécies vegetais. $\mathrm{O}$ objetivo desta pesquisa foi testar o ultrassom e imersão em água como promotores de vigor a sementes e plântulas de $C$. quercifolius. Para tal, sementes de $C$. quercifolius foram submetidas aos tratamentos por meio do esquema fatorial $2 \times 4$ [F1 - Imersão em água por $24 \mathrm{~h}$ (sem e com imersão) e F2 - tempo de exposição ao ultrassom (0, 90, 180 e 270 s), após foram semeadas em canteiro e analisadas por 21 dias com a aferição de emergência e vigor. A imersão em água por $24 \mathrm{~h}$ é efetivo tratamento para promover o vigor de sementes e plântulas de $C$. quercifolius.

PALAVRAS-CHAVE: Bioma Caatinga, Tecnologia de Sementes, Inovação. 


\section{INTRODUCTION}

Caatinga biome is a Brazilian formation forest with xerophytic plants, some different ecoregions (ANTUNES et al., 2014; APGAUA et al., 2014; ANDRADE et al., 2015; MENINO et al., 2015; SILVA et al., 2018), with high evapotranspiration, and concentrated rainfall in a short period.

In addition, in Caatinga biome area, is common the disordered anthropogenic actions and climate changes, causing processes such as the loss of biodiversity and desertification (ANTUNES et al., 2014; APGAUA et al., 2014; ANDRADE et al., 2015; MENINO et al., 2015; DRUMOND et al., 2016; SILVA et al., 2018).

Walter et al. (2019) describes that Caatinga biome area it covers about $53.1 \%$ of the territory of the Northeast region of the country, which represents about $882,081 \mathrm{~km}^{2}$ and more than 20 million people living in this vast location (FERREIRA \& CUNHA, 2013).

Currently, there are some efforts to promote a sustainable production of forest essences from Caatinga biome, for example, studies in seedling formation (ANTUNES et al., 2014; ANDRADE et al., 2015; MENINO et al., 2015), bioecology (APGAUA et al., 2014), morphology (LOUREIRO et al., 2013), satellite analyses (SILVA et al., 2018), and thermal image (DIAS JÚNIOR, et al., 2019). However, for some species in Caatinga species have dormancy and this fact can be disturbing the forest production and this fact is poorly studied (Medeiros et al., 2005) or are recommendation the acid treatments to improve the germination to broken the seed resistance in Euphorbiaceae family (LOUREIRO et al., 2013).

The Euphorbiaceae family is an important taxon present in Caatinga biome area (APGAUA et al., 2014; ANDRADE et al., 2015; MENINO et al., 2015; DRUMOND et al., 2016; DIAS JÚNIOR, et al., 2019).

The seeds produced by this family there is a formation of lipoprotein caruncle and a tegument that protect the seeds from environmental factors, but that can allow the seeds to have a low germination and uniformity under commercial conditions (ANDRADE et al., 2005; LOUREIRO et al., 2013; MENINO et al., 2015; DRUMOND et al., 2016). An important example is Cnidoscolus quercifolius Pohl specie (DIAS JÚNIOR, et al., 2019).

C. quercifolius is an important specie in semiarid region because is used to ethnobotanic (medicament) and forage. Also used in reforestation areas because it can be considered a pioneer species. The pharmaceutical industry has requested specimens of this species to produce medicines. For this reason, planting areas must be implemented to prevent them from being removed from nature, in an extractive way, the raw material for this sector (DIAS JÚNIOR, et al., 2019).

Non-acid seed treatments are alternative treatments; they recommend promoting vigor in forest seeds and seedlings, because this treatment can be dangerous to humans and the environmental, according to Lima et al. (2019).

Due these facts described above; treatments more alternative sustainable can be alternative studied to break dormancy of forest seeds. Among these agents can be cited the benefits of Ultrasound (US) and Water Immersion (WI) before sowing. Both wave frequencies are naturally occurring on the planet, being optimized using specific devices. They are renewable; their use is sustainable and has a low cost of implantation. Such uses are of an innovative character, little used and with the potential to use as a promoter of seed germination of different species (RIFNA et al., 2019).

Therefore, the objective of this paper was to test the use of ultrasound and immersion in water to promote vigor in seeds and seedlings of $C$. quercifolius.

\section{MATERIAL AND METHODS}

The experiments were realized in the Seed Technology Laboratory, in Semiarid Nacional Institute (Campina Grande, PB). C. quercifolius seeds used were provided to NEMA group (UNIVASF). These seeds were harvested for six months in the climate chamber $\left(8 \pm 2^{\circ} \mathrm{C}\right.$, in dark) in plastic recipients. In harvest, the seeds have $85 \%$ of germination.

A factorial scheme $2 \times 4$ was used in this research. For this, were used the factor:

1. F1 - Water Immersion (WI) for $24 \mathrm{~h}, 25 \pm 2^{\circ} \mathrm{C}$ and in dark, with two different treatments: immersion and nonimmersion in water treatments;

2. F2 - Time to expose to Ultrasound waves (US), the seeds were submitted to $0,90,180$ or $270 \mathrm{~s}$ at $25 \pm 2^{\circ} \mathrm{C}$. The equipment Ultrasound Bath (model STD; frequency of 42 $\mathrm{kHz}$; BioWash), in according to Venâncio and Martins (2019). One hundred and fifty seeds were used in each treatment.

The seeds were sowed on soil (Table 1) for thirty days, in protected environment greenhouse (sombrite 50\%). The experiment was made in Experimental Station of the National Institute of the Semi-arid (INSA), Research Unit of the Ministry of Science, Technology, and Innovation (MCTI). Located in the municipality of Campina Grande, PB $\left(7^{\circ} 16^{\prime} 55^{\prime \prime} \mathrm{S}\right.$ and $\left.35^{\circ} 57^{\prime} 88^{\prime \prime} \mathrm{W}\right)$. 
Table 1. Chemical quality to soil used to sowing $(0-20 \mathrm{~cm}$ of deep).

\begin{tabular}{|c|c|c|c|c|c|}
\hline $\mathrm{pH}$ & $\mathbf{P}$ & $\mathrm{K}^{+}$ & $\mathrm{Na}^{+}$ & $\mathrm{H}^{+}+\mathrm{Al}^{+3}$ & $\mathrm{Al}^{+3}$ \\
\hline $\mathrm{H}_{2} \mathrm{O}(1: 2,5)$ & \multicolumn{2}{|c|}{$\mathrm{mg} \cdot \mathrm{dm}^{3}$} & \multicolumn{3}{|c|}{ cmolc. $\mathrm{dm}^{3}$} \\
\hline 5.4 & 3.3 & 98.09 & 0.11 & 3.37 & 0,2 \\
\hline $\mathrm{Ca}^{+2}$ & $\mathrm{Mg}^{+2}$ & V\% & CTC & OM & \\
\hline \multicolumn{4}{|c|}{ cmolc. dm ${ }^{3}$} & g.kg & \\
\hline 3.34 & 0.32 & 54.4 & 7.39 & 6.46 & \\
\hline
\end{tabular}

P, K, Na: Mehlich Extractor 1; $\mathrm{H}+\mathrm{Al}$ : Calcium acetate Extractor $0.5 \mathrm{M}, \mathrm{pH}$ 7.0; pH 7.0; Al, $\mathrm{Ca}, \mathrm{Mg}: \mathrm{KCl} 1 \mathrm{M}$ Extractor; OM.: Organic matter - WalkleyBlack; V\%:

During this period, variables were analyzed to assess vigor, according to the following methodologies:

A. First Emergency Count Percentage (FC), with the count and production of the percentage of seedlings that emerged after 15 days of sowing.

$$
F C=\left(\frac{N G}{N S}\right) * 100
$$

Where: NG - number of germinate seeds and NS - number of seeds sowing.

B. Final Emergency Count Percentage (E), with the count and production of the percentage of seedlings that emerged after 30 days of sowing.

$$
E=\left(\frac{T G}{N S}\right) * 100
$$

Where: TG - number of germinate seeds and NS - number of seeds sowing.

C. Emergency Speed Index (ESI), with the stand emergency count every two days depending on the sample space of 30 days after sowing. The following formula is used for this calculation:

$$
E S I=\frac{\mathrm{N} 1}{\mathrm{D} 1}+\frac{N 2}{D 2}+\ldots .+\frac{N n}{D n}
$$

Where: $\mathrm{ESI}=$ emergency speed index; $\mathrm{N}=$ number of seedlings verified on the counting day; $D=$ number of days after sowing in which the counting was carried out (CARVALHO and NAKAGAWA, 2012).

D. Average Emergency Time (AET), using the formula:

$$
A E T=\sum \frac{\text { niti }}{\text { ni }}
$$

where: $\mathrm{ni}=$ number of seeds germinated per day; $\mathrm{ti}=$ incubation time; $i=1 \rightarrow 63$ days. Unit: days (CARVALHO and NAKAGAWA, 2012).
E. Average Emergency Speed (AES), using for this parameter the formula

$$
A E S=\frac{1}{\mathrm{AET}}
$$

$\mathrm{AET}=1$ / $\mathrm{t}$ where: $\mathrm{t}$ = average germination time. Unit: days ${ }^{1}$ (CARVALHO and NAKAGAWA, 2012).

H. Total Dry Weight per Emergency Seedling (TDW), at thirty days of sowing, with the calculation of dry weight $\left(60^{\circ} \mathrm{C}\right.$ for four days) in an oven with forced ventilation and subsequent weighing.

$$
T W D=\frac{\mathrm{wd}}{\mathrm{NG}}
$$

Where: WD = average weight; NG - number of germinate seeds.

I. Seedlings Normal (NOR): the seedling that emergered with normal characters, in according to Brasilian Seed Analisys Rules (Brasil, 2009).

$$
N O R=\left(\frac{N O R}{N E}\right) * 100
$$

Where: NG - number of normal emergence seedlings and $\mathrm{NE}$ - number of seeds emergered.

J. Seedlings Abnormal ( $A B)$ : the seedling that emergered with normal characters, in according to Brasilian Seed Analisys Rules (Brasil, 2009).

$$
A B=\left(\frac{A B}{N E}\right) * 100
$$

Where: $A B$ - number of abnormal emergence seedlings and $\mathrm{NE}$ - number of seeds emergered.

The experiment was set up in random blocks. Six repetitions per treatment were used in this research; each of these repetitions had 25 seeds sown. The data obtained were compiled in Excel ${ }^{\circledR}$ spreadsheets for the calculations described previously. The statistical analysis used was ANOVA and the Tukey test were performed to visualize the differences between the means, both performed in the

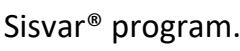

\section{RESULTS AND DISCUSSION}

For the Anova test, we can understand about factor F1 (water immersion) that only the variables percentage of first count, and emergency $(p<0.01)$ and non-germinate seeds $(p<0.05)$ were significant to $F$ test. For factor F2 (time of exposure) anyone variable was significant $(p<0.05)$, 
except the percentage of first count $(p<0.05)$. The interaction between the factors were not significant for all variables evaluated (Table 2 ).

Table 2. Anova results (F-values) to Cnidosculus quercifolius seed treatment in $2 \times 4$ squama [F1 - Immersion in water (Immersion and non-immersion) and F2 Time to exposure to Ultrasound Waves $(0,90,180$ and $270 \mathrm{~s})$ ] about the variables: Percentage of First Count (FC), Emergence (E) and Seedlings Normal (NOR) and Abnormal (AB); Emergence Speed Index (ESI), Average Emergency Time Index (AET), Average Emergency Speed Index (AES); and Total Dry Weight (TDW).

\begin{tabular}{|c|c|c|c|c|c|}
\hline SS & DF & FC & E & SEI & AET \\
\hline F1 & 1 & $56.890 * *$ & $19.163 * *$ & 3.123 NS & $0.73 \mathrm{NS}$ \\
\hline F2 & 3 & $2.801 \mathrm{NS}$ & 1.305 NS & $0.7800 \mathrm{NS}$ & $0.103 \mathrm{NS}$ \\
\hline F1X F2 & 3 & 0.050 NS & $1.046 \mathrm{NS}$ & 0.207 NS & $1.047 \mathrm{NS}$ \\
\hline \multicolumn{2}{|c|}{ CV (\%) } & 24.48 & 25.55 & 24.65 & 4.05 \\
\hline \multicolumn{2}{|c|}{ GERAL STANDART } & 26.58 & 39.75 & 5.25 & 15.50 \\
\hline SS & DF & VMG & NOR & $A B$ & TDW \\
\hline $\mathrm{F} 1$ & 1 & $0.827 \mathrm{NS}$ & $0.882 \mathrm{NS}$ & 0.882 NS & $0.415 \mathrm{NS}$ \\
\hline F2 & 3 & 0.105 NS & 2.684 NS & 2.684 NS & $3.273 *$ \\
\hline F1X F2 & 3 & $1.012 \mathrm{NS}$ & $1.540 \mathrm{NS}$ & $1.540 \mathrm{NS}$ & $6.783 \mathrm{NS}$ \\
\hline \multicolumn{2}{|c|}{ CV (\%) } & 4.02 & 18.09 & 60.37 & 28.73 \\
\hline \multicolumn{2}{|c|}{ GERAL STANDART } & 47.00 & 76.94 & 23.05 & 6.81 \\
\hline
\end{tabular}

SS - source of square; DF - degrees of freedom; CV - Coefficient of Variation; *Significative to $1 \%(p<0.01) ;{ }^{* *}$ Significative to $5 \%(p<0.05)$, and NS - non-significative ( $p>0.05)$.

For immersion factor, in single, were 17.84 and $13.57 \%$ above the general average to Percentage of First Count and Emercence. For these variables, there was no significant difference between the values obtained for this factor (Tukey test). However, it can be noted that there is a predominance of values greater than the general average to be seen in the treatment with immersion, except for the variables ESI, ABN and TDW (Table 3).

For immersion in water (Factor 1), in single, for variable Percentage of First Count the treatment 180s have the large result, too it is statistically equal to 0 and 90 s and different do 270s (Tukey test). And for variable Total Dry Weight the treatment 90s have the large result, too it is statistically equal to 0 and 180 s and different do 270 s (Tukey test).

For variables non-assigned, there were non-significant difference between the average obtained for this factor (Tukey test). Nevertheless, it can be noted that there is a predominance of values greater than the general average to be seen in the treatment with immersion, except for the variables ESI, AB and TDW (Table 4).
Table 3. Averages and Tukey test to Cnidosculus quercifolius seed treatment for F2 - Time to exposure to Ultrasound Waves $(0,90,180$ and 270 s). Variables: Percentage of First Count $(F C)$, Emergency (E), and Seedlings Normal (NOR) and Abnormal (ABN); Emergence Speed Index (ESI), Average Emergency Time Index $(\mathrm{AET})$, Average Emergency Speed Index (AES); and Total Dry Weight (TDW).

\begin{tabular}{ccccc}
\hline IMERSION & FC & E & SEI & AET \\
\hline NON-IMMERSION & $19.50 \mathrm{~A}$ & $33.33 \mathrm{~A}$ & 5.58 & 15.42 \\
IMMERSION & $33.66 \mathrm{~B}$ & $46.160 \mathrm{~B}$ & 4.92 & 15.58 \\
STANDAR ERROR & 1.32 & 2.07 & 0.26 & 1.12 \\
\hline IMERSION & VMG & NOR & AB & TDW \\
\hline NON-IMMERSION & 0.06 & 75.05 & 24.94 & 6.99 \\
IMMERSION & 0.06 & 78.82 & 21.17 & 6.63 \\
STANDAR ERROR & 0.0005 & 2.84 & 2.84 & 0.39 \\
\hline Similar letters in column is not different between them.
\end{tabular}

Table 4. Averages and Tukey test to Cnidosculus quercifolius seed treatment for F1 - Immersion in water (Immersion and non-immersion). Variables: Percentage of First Count (FC), Emergence (E) and Seedlings Normal (NOR) and Abnormal (AB); Emergence Speed Index (ESI), Average Emergency Time Index (AET), Average Emergency Speed Index (AES); and Total Dry Weight (TDW).

\begin{tabular}{ccccc}
\hline ULTRASOUND & FC & E & IVE & TMG \\
\hline 0 & $25.33 \mathrm{AB}$ & 36.66 & 5.20 & 15.48 \\
90 & $26,33 \mathrm{AB}$ & 40.00 & 4.85 & 15.90 \\
180 & $31.00 \mathrm{~B}$ & 38.00 & 5.29 & 15.46 \\
270 & $23.66 \mathrm{~A}$ & 44.33 & 5.65 & 15.47 \\
STANDAR ERROR & 1,87 & 2.93 & 0.37 & 0.18 \\
\hline ULTRASOUND & VMG & NOR & AB & TDW \\
\hline 0 & 0.64 & 73.59 & 36.40 & $7.34 \mathrm{AB}$ \\
90 & 0.64 & 85.65 & 14.34 & $7.65 \mathrm{~B}$ \\
180 & 0.64 & 78.03 & 29.51 & $6.90 \mathrm{AB}$ \\
270 & 0.64 & 70.48 & 29.51 & $5.35 \mathrm{~A}$ \\
STANDAR ERRO & 0.0007 & 4.01 & 4.01 & 0.56 \\
\hline
\end{tabular}

Similar letters in column is not different between them.

The water immersion treatment was more efficient than non-immersion treatment (Table 2 - 4). This treatment is remanded for some authors to Beta vulgaris seeds for two hours of water immersion (SILVA et al., 2005), Centrosema plumieri seeds for $24 \mathrm{~h}$ of water immersion (GAMA et al., 2011) and Bowdichia virgilioides seeds for water $20 \mathrm{~min}$ of immersion (SMIRDELE and SCHWENGBER, 2011).

These facts can be showed in treatment based on the continued hydration of the tissues and the favor of water 
entering the seeds due to the action of the porosity of the integument seeds (RIFNA et al., 2019). For the $C$. quercifolius seeds, the cerose coat that recover the tegument can be broken with this treatment, probably (DIAS JÚNIOR, et al., 2019). In general, Dry lands biome seeds respond well to immersion in water before sowing in according to Lima et al. (2019).

In addition, probably, the ultrasound waves can be affecting the $C$. quercifolius for natural oil content found in Euphorbiaceae plants (ANDRADE et al., 2005; LOUREIRO et al., 2013; MENINO et al., 2015; DRUMMOND et al., 2016). These waves can agitate organic components, leading to heating and this may have been harmful to these studied seeds (RIFNA et al., 2019).

About the US benefits to promoting and standardizing the emergency, we can describe these examples: seeds of Senna multijuga and Phaseolus vulgaris, respectively (Venâncio and matins, 2019).

In contrast, Venâncio and Martins (2019) state in their work that the use of US can be beneficial for promoting and standardizing the germination of Senna multijuga and Phaseolus vulgaris, respectively. According to Azimi et al. (2019), important seed components can be affected to Microwave incidence.

Probably, the US waves in the frequency and in the period of exposure to which the $C$. quercifolius seeds were exposed in this research promoted greater wear of all tissues, as described by Miano et al. (2019) and Venâncio and Martins (2019). Including the embryo and may have also facilitated the pathogenesis of microorganisms that were naturally associated with the seeds worked in this research.

\section{CONCLUSION}

The water immersion to $24 \mathrm{~h}$ is an efficient treatment to improve vigor to $C$. quercifolius seeds and seedlings. Ultrasound waves can be interesting to the $C$. quercifolius seeds and seedlings, but it must test to improved understand about it.

\section{CONGRATULATIONS}

We are grateful to the Center for Agroecology and Desertification in Dry Lands, linked to the National Institute of the Semi-Arid (MCTI) for the support to development of sustainable technologies for Brazilian Semiarid Area.

We would also like to thank the group of Ecology and Environmental Monitoring - NEMA/UNIVASF, the Project for the Integration of the São Francisco River with the
Hydrographic Basins of the Northeast - PISF (Brazil) and the Ministry of Regional Development - MDR (Brazil) for the availability of the seeds and for the kindness in providing material used in this research. More information about this group can be viewed on the website: http://www.nema.univasf.edu.br/site/index.php?page=h ome> and accessed 26.10.2020.

\section{REFERENCES}

ANDRADE, L.A. et al. Analyses of the stract of two Caatinga physionomy in São João do Cariri, Paraiba State. Cerne, v.11, n.3, p.253-262, 2015.

ANTUNES, C.G.C. et al. Desenvolvimento de mudas de catingueira em diferentes substratos e níveis de luminosidade. Cerne, v.20, n.1, p.55-60, 2014

APGAUA, D.M.G. et al. Tree community structure in a seasonally dry tropical forest remnant, Brazil. Cerne, v.20, n.2, p.173-182, 2014.

AZIMI, N. et al. (2019) Intensification of liquid-liquid extraction in a tubular sono-extractor using $1.7 \mathrm{MHz}$ ultrasound and $\mathrm{SiO}_{2}$ nanoparticles. Chemical Engineering and Processing-Process Intensification, n.137, p.28-38, 2019.

DIAS JÚNIOR, A.F. et al. Thermal profile of wood species from the Brazilian semi-arid region submitted to pyrolysis. CERNE, v.25, n.1, p.44-53, 2019.

DRUMOND, M.A et al. Produção e distribuição da biomassa de Jatropha curcas no semiárido brasileiro. CERNE, v.22, n.1, p.35-41 2016.

FERREIRA, R.A.; CUNHA, M.C.L. Morphological aspects of seeds, seedlings and development of changes Tabebuia aurea (Tabebuia caraiba (Mart) Bur.) - Bignoniaceae and pereiro (Aspidosperma pyrifolium Mart.) - Apocynaceae Revista Brasileira de Sementes, v.22, p.134-143, 2013.

GAMA, J.S.N. et al. Superação de dormência em sementes de Centrosema plumieri Benth. Revista Brasileira de Sementes, v.33, n.4, p.643-651, 2011.

LIMA, M.L.S. et al. Germinação e vigor de sementes de Caesalpinia ferrea Mart. ex. Tul. var. ferrea submetidas a diferentes regimes de luz e temperaturas. Ciência Florestal, v.29, n.3, p.1180-1186, 2019

LOUREIRO, M.B. et al. Caracterização morfoanatomica e fisiológica de sementes e plântulas de Jatropha curcas L. (Euphorbiaceae). Revista árvore, v.37, n.6, p.1093-1101, 2013.

MEDEIROS FILHO, S. et al. Seed germination and seedling development of Caesalpinia ferrea Mart. ex Tul vr. ferrea in green house and germinator. Revista Ciência Agronômica, v.36, n.2, p.203, 2005.

MEDEIROS FILHO, S.; SILVA, A.P.; FILHA, E.C.S. Seed germination and seedling development of Caesalpinia ferrea Mart. ex Tul vr. 
ferrea in green house and germinator. Revista Ciência Agronômica, v.36, n.2, p.203-208, 2005.

MENINO, G.C.O. et al. Florística e estrutura de florestas tropicais sazonalmente secas. Cerne, v.21, n.2, p.277-291, 2015.

MIANO, A.C. et al. Combining lonizing irradiation and ultrasound technologies: effect on beans hydration and germination. Journal of food science, v.84, n.11, p.3179-3185, 2019.

RIFNA, E.J. et al. Emerging technology applications for improving seed germination. Trends in food science \& technology, v.86, p.95-108, 2019.

SILVA, C.R. et al. Analysis of the phenology dynamics of Brazilian caatinga species with NDVI time series. Cerne, v.24, n.1, p.48-58, 2018.

SMIDERLE, O.J.; SCHWENGBER, L.A.M. Superação da dormência em sementes de paricarana (Bowdichia virgilioides Kunth.). Revista Brasileira de Sementes, v.33, n.3, p.407-414, 2011.

VENÂNCIO, R.S.S.; MARTINS, A.C.G. Overcoming dormancy of Senna multijuga seeds with an ultrasonic probe the comparison with ultrasound and sulfuric acid baths. Ciência Rural, v.49, n.9, e20180904, 2019.

WALTER, L.S. et al. Influence of pre-germination treatments on initial growth of Libidibia ferrea seedlings. Pesquisa Florestal Brasileira, v.38, p.2-6, 2018. 